\title{
BARTTER SYNDROME, A RARE CAUSE OF MALNUTRITION IN CHIDREN
}

\author{
Abdul Khaliq ${ }^{1}$, Rifayatullah $^{2}$, Aneela Ambreen $^{2}$ \\ 1. Noshehra Medical College \\ 2. Naseer Teaching Hospital
}

\begin{abstract}
Three and half year old Haleema presented to OPD with complaints of failure to thrive polydipsia and polyuria. In past she visited different clinicians and hospitals. Scrutiny of the previous record showed alkalosis persistently, but other electrolytes values were different from different labs. We admitted her and investigations were repeated, which showed hypo-kalemia, hypo-chloremia, hypo-natremia, metabolic alkalosis, hyper-calciuria, and normal urine osmolality and specific gravity. Her plasma rennin and aldosterone level were also raised. She was discharged on treatment for Bartter syndrome. On follow up, 15 days later her weight and clinical symptoms were improved.
\end{abstract}

\section{KEY WORDS:}

Bartter Syndrome, Malnutrition, Children.

\section{INTRODUCTION}

Malnutrition is the most prevalent public health concern in most of under developed and developing countries. Poor household level of food security, access to health and sanitation

Correspondence:

Dr. Rifayatullah

Naseer Teaching Hospital

Contact: 0334-8954974

Email: drrifayat@yahoo.com

https://doi.org/10.37762/jgmds.2-2.55 services and child caring practices are the three main reason which results in malnutrition in our setup ${ }^{1}$.In south Asian countries, malnutrition is the most common public health issue in children under the age of five years. About half of the world's malnourished children reside in India, Pakistan and Bangladesh. In developing countries, $16 \%$ of children are born with low birth weight. In south Asia, $27 \%$ of neonates are born with low birth weight. In Pakistan, $27 \%$ of our children <5years are underweight and $32 \%$ are stunted. $42 \%$ of our pregnant women and $47 \%$ of our children $<5$ years are anemic. In last, nearly $50 \%$ of our population is malnourished ${ }^{1,2}$.

Good nutrition in the very young age is very important because the effects of under nutrition in the early life are long lasted in terms of physical, social, mental and intellectual development of the child ${ }^{2}$. The most immediate and dangerous complication of malnutrition is premature death. The risk of death is increased even with mild malnutrition and thereby it increases exponentially as the severity of malnutrition is increased. If a child reaches his $1^{\text {st }}$ birthday in malnourished state, he suffers irreversible physical and cognitive damage, and his future life, welfare and economic wellbeing are badly affected ${ }^{1}$. In south Asia Pakistan has the second highest infant and child mortality rates $^{3}$. In 2005 hours under 5 years child mortality rate was 101/1000 live births and malnutrition underlies much of this child mortality ${ }^{4}$. There are so many causes of malnutrition, which are broadly divided into primary and secondary. Primary malnutrition is because deficient intake of calories/proteins, while secondary is because of excessive caloric expenditure that is not met, or food quantity and quality are good but it is not assimilated properly ${ }^{1}$. In this report we will present a case of secondary malnutrition which was extensively investigated at different hospital in Peshawar, but no cause was found. She had a changing picture of clinical features, and so she was investigated at different lines. She received different treatment regimens, but with very little improvement. And at last she was proved to be a case of Bartter syndrome. 


\section{CASE REPORT}

Three and a half year old Haleema presented to us in OPD on $19^{\text {th }}$ may 2015 , with the main complaint of not gaining weight. She also had polyuria, polydipsia and vomiting since last two years. On examination, she was emaciated, irritable and having doll's like faces. Her weight was $7.8 \mathrm{~kg}$, and height was $88 \mathrm{~cm}$. She always had a bottle of water in her hands. Both her height and weight were below the $5^{\text {th }}$ centile on WHO growth charts. She was dehydrated. Her pulse rate was 110BPM. Her respiratory, abdominal, cardiovascular and central nervous system examination was unremarkable.

When she was one and a half years old she was admitted in a tertiary care hospital in Peshawar, with complaints of vomiting and not gaining weight. There her serum electrolytes were deranged with raised potassium and decreased sodium. For that reason her serum $17-\mathrm{OH}$ progesterone level was also done that was normal. There her ABGs were also done that showed $\mathrm{PH}$ of $7.624, \mathrm{HCO} 3$ of $20.5 \mathrm{mmol} / \mathrm{L}, \mathrm{PCO} 2$ of $20.3 \mathrm{mmHg}$, and $\mathrm{PO} 2$ of $82.2 \mathrm{mmHg}$. Also her ultrasound report was normal. But unfortunately they got discharge on will, before she was properly diagnosed. After that, in the last two years she visited different hospitals and private clinics, with different set of complaints, the common to all was not gaining weight, polydipsia and polyuria. Here with us, her urine examination was normal, with normal osmolality and specific gravity. Serum sodium was $132.6 \mathrm{mmol} / \mathrm{L}$, potassium was $2.04 \mathrm{mmol} / \mathrm{L}$ and chloride was $91.3 \mathrm{mmol} / \mathrm{L}$. Serum alkaline phosphatase was normal but serum calcium was $8.2 \mathrm{mg} / \mathrm{dl}$. Serum magnesium was within normal range. Her serum creatinine and urea was also normal. Her $\mathrm{Hb}$ was $10 \mathrm{~g} / \mathrm{dl}$. TLC, DLC and platelets count was also normal. MCV was 68.2fl. Her ABGs showed PH of 7.58 and $\mathrm{HCO} 3$ of $31.1 \mathrm{mmol} / \mathrm{L}$. Her ultrasound abdomen showed bilateral tiny renal concretions. Urinary chloride was $286 \mathrm{mmol} / 24$ hours (normal: $110-250$ ), and urinary calcium was $380 \mathrm{mmol} / 24$ hours (normal: $100-$ 300). Plasma rennin level was $>500 \mathrm{ulU} / \mathrm{ml}$ (normal: erect=4.4-46.1, supine=2.8-39.9) and aldosterone level was 35ng/dl (normal: standing=4-31, recumbent=1-16). So she was diagnosed to be a case of Bartter syndrome and treatment was started. On follow up, 15 days after discharge her weight was $8.6 \mathrm{~kg}$, and she was improved symptomatically.

\section{DISCUSSION}

Bartter syndrome is a rare disorder of renal tubules. It was $1^{\text {st }}$ described in 1962 by frederich bartter and his colleagues ${ }^{5}$. It is clinically and genetically hetero-genetic disorder characterized by renal salt wasting, hyper-calciurea, hypo-kalemia, metabolic alkalosis, and normotensive hyperreninemic hyperaldosteronism ${ }^{6}$. It is transmitted in auto-somal recessive fashion; therefore it is more common in the off springs of consanguineous parents ${ }^{5}$. Clinically Bartter syndrome is classified into two groups, depending upon the age at onset, antenatal/neonatal and classic. Genetically barter syndrome is classified into five types, depending on the underlying gene mutation. All of these mutant genes are expressed in the tubular epithelial cells of thick ascending limb of loop of henle. In type-1 there are loss-of-function mutations of SLC12A1 which encodes the apical sodium-potassium-chloride co transporter (NKCC2). In bartter syndrome type-2 there are loss-of-function mutations of $K C N J 1$, which encodes the apical inwardly-rectifying potassium channel (ROMK). BS type III is caused by loss-of-function mutations of CLCNKB which encodes the baso-lateral chloride channel $(\mathrm{CIC}-\mathrm{Kb})$. BS type IV is caused by loss-of-function mutations of $B S N D$ which encodes barttin and BS type $\mathrm{V}$ is caused by gain-of-function mutations of CASR which encodes the baso-lateral calcium sensing receptor $(C A S R)^{6}$. These defects results in defective reabsorption of sodium, potassium, chloride, hydrogen iron and calcium in the thick ascending limb of loop of henle, subsequently leading to hypo-kalemic, hypo-chloremic, metabolic alkalosis. Although hyper-calciuria is an important feature, hypo-calcemia and hypo-natremia is usually not that much severe. The antenatal/neonatal bartter usually presents in neonatal or infantile life, with severe phenotypic 
features like neonatal salt wasting and recurrent dehydration. These patients also usually have history of maternal poly-hydromnios. The classic bartter syndrome usually presents in childhood, with milder phenotype of recurrent episodes of mild dehydration, polydipsia, polyuria and failure to thrive. The dysmorphic features like triangular faces, large eyes and protruding ears can be present in both types ${ }^{5,7}$. The diagnosis is mostly based on clinical history and characteristic bio-chemical picture of hypo-kalemia, hypo-chloremia, metabolic alkalosis, hyper-calciuria and increased excretion of chloride in urine?

Treatment is supportive, by preventing dehydration, care of good and enough nutrition, and correcting the electrolytes derangement. These patients especially, needs very high amount of potassium daily. Potassium sparing diuretics are also helpful. Indomethacin is also given especially in antenatal/neonatal form. With accurate management the prognosis is usually good. Some patient may develop chronic interstitial nephritis and chronic renal disease ${ }^{7}$. Our patient was a case of classic Bartter syndrome, leading to secondary malnutrition. Although Bartter syndrome is not a common cause of malnutrition, this case report will emphasize not to ignore the rare causes of malnutrition, if we cannot find any common cause. Putting all the malnutrition into the primary one, after investigating the common causes, and ignoring the important clues in history is not a realistic approach.

\section{REFERENCES}

1. Alderman H, Shekar M. Nutrition, food security and health. In: Kliegman RM, Stanton BF, Geme JWS, Schor NF, Behrman RE, editors. Nelson textbook of paediatrics. $19^{\text {th }}$ ed. Philadelphia:Saunders Elsevier; 2011.p. 170-9.

2. Hirani SA. Malnutrition in young Pakistani children. J Ayub Med Coll Abbottabad 2012;24(2):150-3.

3. Bhutta ZA, Hyder AA, Ali N. Defining a new challenge for health systems: perinatal health in Pakistan. In: Bhutta ZA, editor. Perinatal and newborn care in South Asia: priorities and action. $2^{\text {nd }}$ ed. USA: Oxford University Press; 2007.

4. World Health Statistics. World Health Organization 2008. Available at URL: http://www.who.int/whosis/mort/profiles/mort_emro_pak_pakistan.pdf.

5. Bhat YR, Vinayaka G, Sreelakshmi K. Antenatal bartter syndrome: a review. Int J Pediatr 2012;2012:857136.

6. Lee SE, Han KH, Jung YH, Lee HK, Kang HG, Moon KC, et al. Renal transplantation in a patient with Bartter syndrome and glomerulosclerosis. Korean J Pediatr 2011;54(1):36-9.

7. Sreedharan R, Avner ED. Bartter and Gitelman Syndromes and Other Inherited Tubular Transport Abnormalities. In: Kliegman RM, Stanton BF, Geme JWS, Schor NF, Behrman RE, editors. Nelson textbook of paediatrics. $19^{\text {th }}$ ed. Philadelphia:Saunders Elsevier; 2011.p. 1813-14.

\section{CORRIGENDUM}

In the issue Vol. 02 No.01 (Sep 2015-March 2016) of JGMDS in the CASE REPORT titled "Fibromatosis In Maxillofacial Region", the name of the authors were aberrantly printed by omitting two authors. Henceforth the author list for the said article should be read as under:

Jawad Ahmad Kundi ${ }^{1}$, Shahid Khan Khattak ${ }^{1}$, Syed Murad Ali Shah ${ }^{1}$, Amina Gul Mannan ${ }^{1}$, Faryal Gul ${ }^{1}$, Mohammad Umar $^{1}$, Ajmal Khan ${ }^{1}$

1. Sardar Begum Dental College 